\title{
Biology and epidemiology of Valdensinia heterodoxa Peyronel - pathogen of highbush blueberry
}

\author{
Biologia i epidemiologia Valdensinia heterodoxa Peyronel \\ - patogena borówki wysokiej
}

\author{
Wojciech Kukuła*, Ewa Mirzwa-Mróz
}

\begin{abstract}
Summary
Valdensinia heterodoxa Peyronel is polyphagous fungus infecting many species of herbaceous plants, shrubs and trees. The geographical range of the pathogen area includes Europe, North America and Asia. The fungus was classified as ascomycetes (Sclerotiniaceae). The fungus was rarely observed at a perfect stage. The pathogen spreads by conidia - staurospores and overwinters as sclerotia or mycelium on fallen infected leaves. The pathogen causes leaf spots and defoliation of the shoot. In the recent years, the pathogen has begun to play a significant role among the economically important crops including bilberry and highbush blueberry. In Polish climatic conditions the pathogen was recorded back in the 20's of the XX-century, but its biology and epidemiology have not been well recognized yet. Due to the increasing importance of highbush blueberry crop, it is worthwhile to extend knowledge of life cycle and harmfulness of $V$. heterodoxa with respect to this species crop.
\end{abstract}

Key words: Valdensinia heterodoxa; staurospores; epidemiology; highbush blueberry

\section{Streszczenie}

Valdensinia heterodoxa jest grzybem zasiedlającym wiele gatunków roślin zielnych, krzewów i drzew. Zasięg występowania patogena obejmuje rejon Europy, Ameryki Północnej oraz Azji. Grzyb został zaklasyfikowany do typu Ascomycota, rodziny Sclerotiniaceae. W stadium doskonałym jest rzadko obserwowany. Rozprzestrzenia się przez zarodniki konidialne zwane staurokonidiami. Zimuje w postaci sklerocjów lub grzybni na opadłych, porażonych liściach. Patogen jest sprawcą plamistości liści oraz defoliacji pędów. W ostatnich latach zaczyna odgrywać znaczącą rolę jako patogen roślin uprawnych ważnych gospodarczo, m.in. borówki czarnej i borówki wysokiej. W warunkach klimatycznych Polski patogen był notowany już w latach 20. XX wieku, jednak jego biologia i epidemiologia nie jest jeszcze dobrze poznana. W związku ze wzrastającym znaczeniem upraw borówki wysokiej, wydaje się niezbędne poszerzenie wiadomości dotyczących cyklu życiowego oraz szkodliwości $V$. heterodoxa w stosunku do roślin tego gatunku.

Słowa kluczowe: Valdensinia heterodoxa; staurokonidia; epidemiologia; borówka wysoka

Szkoła Główna Gospodarstwa Wiejskiego w Warszawie Wydział Ogrodnictwa, Biotechnologii i Architektury Krajobrazu Samodzielny Zakład Fitopatologii

Nowoursynowska 166, 00-787 Warszawa

*corresponding author: wojciech_kukula@sggw.pl 


\section{Wstęp / Introduction}

Powierzchnia upraw borówki wysokiej (Vaccinium corymbosum L.) w naszym kraju z roku na rok wzrasta. Wraz z nią rośnie liczba nowych, niewystępujących do tej pory chorób i szkodników. Jedną z nich jest plamistość liści borówki wysokiej powodowana przez grzyb Valdensinia heterodoxa. Objawy charakterystyczne dla sprawcy tej choroby w Polsce zanotowano w 2011 roku. W jednej ze szkółek matecznych roślin jagodowych zlokalizowanej w województwie mazowieckim zaobserwowano wówczas nekrotyczne, koncentrycznie-strefowane plamy na liściach odmiany Bluecrop. Podobne objawy odnotowano także na liściach borówki czarnej ( $V$. myrtillus) (Dzięcioł i wsp. 2014). Obie rośliny należą do rodziny wrzosowatych (Ericaceae), dlatego istnieje wysokie prawdopodobieństwo rozprzestrzenienia się $V$. heterodoxa na plantacje towarowe borówki wysokiej w Polsce, podobnie jak miało to miejsce w Kanadzie i Japonii, gdzie patogen stanowi już poważny problem (Annis i Yarborough 2009; Nekoduka i wsp. 2012). Plantacje w naszym kraju zakładane są najczęściej na obrzeżach lasów, w których nierzadko rośnie borówka czarna, powszechnie porażana przez tego grzyba. Jedynie dokładne poznanie biologii i epidemiologii $V$. heterodoxa pozwoli w przyszłości na opracowanie metod ochrony upraw ważnych gospodarczo przed tym patogenem.

\section{Historia i taksonomia grzyba History and taxonomy of fungus}

Nazwa patogena podlegała wielokrotnie zmianom. W 1897 Allescher opisał tego patogena jako Gloeosporium myrtilli Allesch. (Allescher 1897) Stadium niedoskonałe anamorfę grzyba zaobserwował i opisał także Peyronel w 1923 roku nadając jej nazwę Valdensia heterodoxa Peyr. Pierwszy jej człon wywodzi się od Doliny Waldensów w północno-zachodnich Włoszech (teren Piemontu), w której znaleziono porażoną borówkę czarną (Peyronel 1923). Zarodniki konidialne (konidia) w kształcie gwiazd, podobne do tych opisanych przez Alleschera i Peyronela, w swoich badaniach zaobserwował również Kujala w 1946 roku. Ze względu na ich podobieństwo badacz zaproponował dla tych grzybów jedną nazwę Saliastrum myrtilli (Allesch.) Kujala (Kujala 1946). W 1962 roku Petrak dla wszystkich opisanych do tego czasu grzybów tworzących zarodniki konidialne gwiaździstego kształtu o liczbie ramion od 3 do 6 utworzył wspólny takson o nazwie Valdensia myrtilli (Allesch.) Petr. (Redhead i Perrin 1972b). Następnie Gjaerum w 1970 roku (podobnie jak wcześniej Peyronel) określił sprawcę plamistości liści borówki czarnej jako $V$. heterodoxa Peyr (Gjaerum 1970). Nazwa ta obowiązuje do dziś. Stadium niedoskonałe tego grzyba zostało również zaobserwowane przez Redhead i Perri (1972a) na porażonych liściach Gaultheria shallon Pursh. rosnących w kanadyjskiej prowincji British Columbia. Pierwotnie zostało ono opisane jako Asterobolus gaultheriae Redhead i P.W. Perrin. Etymologia tej nazwy związana jest z kształtem konidiów (z gr. aster - gwiazda) oraz mechanizmem ich uwalniania (z gr. bolos - rzucać).
Ze względu na podobieństwo morfologiczne zarodników konidialnych nazwa ta została uznana jako kolejny z synonimów $V$. heterodoxa (Redhead i Perrin 1972a, b). Stadium doskonałe (teleomorfa) $V$. heterodoxa zostało zaobserwowane i opisane po raz pierwszy w 1953 roku przez Peyronela (Peyronel 1953). Grzyb został zaklasyfikowany do typu Ascomycota, rzędu Helotiales, rodziny Sclerotiniaceae (Kirk i wsp. 2008).

\section{Zakres roślin żywicielskich patogena The host range of the pathogen}

$V$. heterodoxa jest gatunkiem polifagicznym. Patogen został zidentyfikowany na wielu gatunkach roślin naczyniowych w Europie, Azji i Ameryce Północnej (Redhead 1974; Mel'nik 1981; Mułenko i Woodward 1996; Mułenko i wsp. 2008; Nekoduka i wsp. 2012). Występowanie grzyba jest ściśle związane z warunkami klimatycznymi panującymi w danym regionie. Grzyba notowano najczęściej na roślinach rosnących $\mathrm{w}$ lasach lub innych zadrzewieniach wilgotnych terenów podgórskich. Wysoka wilgotność powietrza jest jednym z głównych czynników umożliwiających uwalnianie i kiełkowanie zarodników konidialnych, jak również dalszy wzrost i rozwój grzyba. Właśnie w takich warunkach grzyb został zaobserwowany po raz pierwszy w 1923 roku na liściach borówki czarnej, znalezionej $\mathrm{w}$ dolinach górskich strefy leśnej Piemontu (Włochy), na wysokości 1200-1800 m n.p.m. (Siemaszko 1934). Roślina była najczęściej atakowana przez $V$. heterodoxa we Włoszech i Norwegii (Gjaerum 1970), gdzie zajmuje znaczne powierzchnie lasów borealnych (Aamlid 2000). Pojedyncze przypadki porażenia odnotowywano również w Niemczech (Bavendamm 1944; Petrak 1962), Rosji (Mel'nik 1981) i na Litwie (Treigiene 1998). Patogena obserwowano często na krzewach borówki czarnej w naturalnych i półnaturalnych lasach Polski i Szkocji (Mułenko i Woodward 1996). W warunkach umiarkowanego klimatu Polski był notowany również na liściach innych krzewów, a także drzew i roślin zielnych, rosnących na terenach Puszczy Białowieskiej, Ojcowa i nad Wigrami (Siemaszko 1929, 1933, 1934).

Występowanie patogena zostało potwierdzone na kontynencie Ameryki Północnej, gdzie oprócz $V$. myrtillus L. porażał także inne rośliny $\mathrm{z}$ rodziny wrzosowatych (Ericaceae). W kanadyjskiej prowincji British Columbia występował na G. shallon, w Quebec porażał $V$. myrtilloides Michx. i V. angustifolium Ait. (Redhead 1979), a w Newfoundland $V$. ovalifolium Sm. (Parmelee 1988). Natomiast w USA został wyizolowany z liści G. shallon, $V$. alaskaense How. i $V$. membranaceum Douglas rosnących na terenie stanów Washington, Oregon i Idaho (Norvell i Redhead 1994). Szczegółowy wykaz roślin porażanych przez Valdensinia heterodoxa w Europie i Ameryce Północnej zamieszczono w tabeli 1.

W 2003 roku w Japońskiej prowincji Iwate patogen po raz pierwszy został odnotowany na borówce wysokiej (Nekoduka i wsp. 2012). Kolejny przypadek na świecie, a pierwszy w Polsce został potwierdzony na roślinach tego samego gatunku w jednej ze szkółek matecznych w 2011 roku. Objawy porażenia zaobserwowano wówczas na liś- 
Tabela 1. Wykaz roślin gospodarzy dla V. heterodoxa w Europie i Ameryce Północnej (według Farr i Rossman 2013)

Table 1. The List of host plant species of $V$. heterodoxa in Europe and North America (by Farr and Rossman 2013)

\begin{tabular}{|c|c|}
\hline Europa - Europe & Ameryka Północna - North America \\
\hline $\begin{array}{l}\text { Asplenium filix-femina } \text { (L.) Bernh (Aspleniaceae), Betula } \\
\text { pubescens Ehrh. (Betulaceae), Convallaria majalis L. } \\
\text { (Canvallariaceae), Corylus avellana L. (Betulaceae), Fagus } \\
\text { sylvatica L. (Fagaceae), Hieracium L. (Asteraceae), Hypericum } \\
\text { L. (Hypericaceae), Oxalis acetosella L. (Oxalidaceae), } \\
\text { Polygonatum multiflorum (L.) All (Canvallariaceae), Quercus } \\
\text { petraea Liebl. (Fagaceae), Q. robur L. (Fagaceae), Rubus } \\
\text { saxatilis L. (Rosaceae), Rubus L. (Rosaceae), Scorzonera } \\
\text { humilis L. (Asteraceae), Sorbus aucuparia L. (Rosaceae), } \\
\text { Trientalis europaea L. (Primulaceae), V. vitis-idaea L. } \\
\text { (Ericaceae) }\end{array}$ & $\begin{array}{l}\text { Acer macrophyllum Pursh. (Sapindaceae), Diervilla lonicera Mill. } \\
\text { (Caprifoliaceae), Dryopteris austriaca (Jacq.) Woyn. } \\
\text { (Dryopteridaceae), Gaultheria shallon Pursh. (Ericaceae), Malus } \\
\text { fusca (Raf.) Schneid. (Rosaceae), Menziesia ferruginea Sm. } \\
\text { (Ericaceae), Polystichum munitum (Kaflu.) C. Presl } \\
\text { (Dryopteridaceae), Pteridium aquilinum (L.) Kuhn. } \\
\text { (Dennstaedtiaceae), Rubus parviflorus Nitt. (Rosaceae), } \\
\text { R. pedatus J.E.Sm. (Rosaceae), R. ursinus L. (Rosaceae), Vaccinium } \\
\text { alaskaense How. (Ericaceae), V. angustifolium Ait. (Ericaceae), } \\
\text { V. membranaceum Douglas. (Ericaceae), V. myrtilloides Michx. } \\
\text { (Ericaceae), V. ovalifolium J.E. Sm. (Ericaceae), V. parvifolium } \\
\text { J.E.Sm. (Ericaceae) }\end{array}$ \\
\hline
\end{tabular}

ciach 30 jednorocznych roślin odmiany Bluecrop. Z liści z widocznymi objawami choroby uzyskano 8 izolatów grzyba. Zostały one zidentyfikowane za pomocą metod tradycyjnych i dostępnych technik biologii molekularnej (Dzięcioł i wsp. 2014).

\section{Objawy i szkodliwość choroby Symptoms and harmfulness of disease}

Objawy choroby powodowane przez $V$. heterodoxa to: okrągłe bądź owalne, strefowane, brązowe lub prawie brunatne, nekrotyczne plamy z ciemnopurpurową obwódką, o średnicy do $1 \mathrm{~cm}$. Obwódka dookoła plamy powstaje wskutek miejscowej produkcji antocyjanowego pigmentu, mającego ograniczyć rozwój grzyba. W miejscach nasłonecznionych zabarwienie obwódki jest intensywniejsze, natomiast plamy są mniejsze w porównaniu z tymi obserwowanymi na liściach roślin rosnących w zacienieniu. Można przypuszczać, że dostęp promieni słonecznych pozytywnie wpływa na uruchomienie reakcji obronnych roślin przez włączenie miejscowej produkcji antocyjanów Peyronel (1923). Ten sam typ objawów obserwowano m.in. na roślinach: Fagus sylvatica w Niemczech (Bavendamm 1944), Sorbus aucuparia i Dryopteris linnaeana w Norwegii (Gjaerum 1970), G. shallon w Kanadzie (Redhead i Perrin 1972a) oraz $V$. corymbosum w Japonii (Nekoduka i wsp. 2012) i w Polsce (Dzięcioł i wsp. 2014).

W zależności od rośliny oraz stopnia porażenia grzyb może powodować przedwczesne opadanie liści i zamieranie roślin. Niektóre $\mathrm{z}$ nich mogą wytwarzać nowe liście, jednak odbywa się to kosztem zahamowania rozwoju pąków kwiatowych na rok następny. W przypadku borówki czarnej oraz pozostałych krzewów owocowych $\mathrm{z}$ rodziny wrzosowatych, wiąże się to $\mathrm{z}$ obniżeniem plonu. Rośliny zazwyczaj nie są $\mathrm{w}$ stanie prawidłowo przygotować się do zimowania przez co stają się mniej wytrzymałe na spadki temperatury w czasie zimy (Hildebrand i Renderos 2007; Annis i Yarborough 2009).

\section{Cykl życiowy i biologia / Life cycle and biology}

W stadium doskonałym grzyb wytwarza małe, wydłużone, jasnobrązowe apotecja o średnicy od 2,5 do $5 \mathrm{~mm}$. Owocniki te wyrastają na długich trzonkach $(2-6 \mathrm{~mm}) \mathrm{ze}$ sklerocjów, tworzących się wzdłuż nerwów głównych opadłych liści. Apotecja początkowo są wklęsłe, ale z czasem, w trakcie dojrzewania, stają się wypukłe. Tworzące się w nich worki są cylindryczne, rozszerzające się ku podstawie, bezwieczkowe i cienkościenne. W każdym worku znajduje się po 8 hyalinowych, zwykle elipsoidalnych zarodników workowych (askospor) o wymiarach 10-12 × 4,5 $\mu \mathrm{m}$ (Gjaerum 1970; Redhead 1974). Owocniki stadium doskonałego tego grzyba w przyrodzie formują się bardzo rzadko (Norvell i Redhead 1994). Dotychczas obserwowali je tylko: Peyronel na liściach $V$. myrtillus we Włoszech w czerwcu 1952 roku (Peyronel 1953), Readhed na liściach $G$. shallon w marcu i kwietniu 1974 roku w Kanadzie (Redhead 1974) oraz Horst-Jensen w 1996 w Norwegii na liściach $V$. myrtillus (Wilkin 2004).

W stadium niedoskonałym $V$. heterodoxa wytwarza krótkie, pojedyncze, proste, hyalinowe, cylindryczne trzonki konidialne, o szerokości 35-45 $\mu \mathrm{m}$. Na ich szczycie powstają wielokomórkowe zarodniki konidialne (konidia) w kształcie gwiazdy, o średnicy 450-600 $\mu \mathrm{m}$ (makrokonidia). Zarodniki te należą do typu staurokonidiów. Ich charakterystyczną cechą są promieniście ułożone ramiona (w liczbie od 4 do 5) ostro, szydlasto zakończone. Centralna komórka konidium jest kulista o wielkości 100-150 $\mu \mathrm{m}$. Na jej górnej powierzchni tworzy się początkowo 40-60 kulistych, cienkościennych guzków, które z czasem rozwijają się w maczugowate wypukłości, ściśle upakowane i oddzielone od komórki centralnej ścianami poprzecznymi (Mułenko i Woodward 1996). Na górnej stronie ramion, w ich części proksymalnej, tworzą się cienkościenne nabrzmienia (8-12), ułożone poprzecznie i ściśle do siebie przylegające. Struktury te i maczugowate komórki nad komórką centralną tworza na górnej stronie konidium mocno ściśniętą palisadę (Zhao i Shamoun 2010). W warunkach dużej wilgotności, komórki tworzące palisadę mogą się powiększać i wtedy końce ramion wyginają się $\mathrm{ku}$ dołowi (Peyronel 1923). W stadium anamorfy grzyb może wytwarzać również drugi rodzaj konidiów-fialokonidia. Są one jednokomórkowe i kuliste, o średnicy 2-2,5 $\mu \mathrm{m}$. Tworzą się na komórkach konidiotwórczych zwanych fialidami, znajdujących się na krótkich bądź długich, hyalinowych lub nieznacznie wybarwionych, wzniesionych trzonkach konidialnych (Redhead i Perrin 1972a). Ten rodzaj zarodnikowania był obserwowany jedynie w warunkach laboratoryjnych na sztucznych podłożach (Zhao i Shamoun 2010). 
Zdolność grzyba do infekcji w dużym stopniu zależy od warunków środowiskowych. Najczęściej patogen ten występuje w lasach w stanowiskach wilgotnych, porażając zarówno liście krzewów, jak i roślinności zielnej (Siemaszko 1929, 1934). Tworzenie się zarodników i proces infekcji są zwykle stymulowane wysoką wilgotnością powietrza utrzymującą się przez dłuższy okres czasu. Takie warunki występują w marcu i kwietniu, kiedy już po 3 dniach dochodzi do wytworzenia zarodników konidialnych, a następnie nawiązania kontaktu pasożytniczego (Hildebrand i Renderos 2007). Optymalna temperatura zarodnikowania mieści się $\mathrm{w}$ przedziale $15-20^{\circ} \mathrm{C}$ (Zhao i Shamoun 2006). Zarówno zbyt niska (poniżej $5^{\circ} \mathrm{C}$ ), jak i zbyt wysoka temperatura (powyżej $30^{\circ} \mathrm{C}$ ) powoduje całkowite zahamowanie rozwoju choroby. Rozprzestrzenianie się zarodników konidialnych na sąsiednie rośliny odbywa się bez udziału wiatru i kropli deszczu (Annis i Yarborough 2009). Czynnikiem ułatwiającym ten proces jest wilgoć, która powoduje pęcznienie komórek ramion i ich składnie się, co skutkuje odepchnięciem zarodników od powierzchni liścia. Siła z jaką uwalniają się konidia powoduje ich przemieszczanie się na odległość około 20-30 cm, po czym upadają one zwykle na sąsiedni liść rośliny żywicielskiej (Peyronel 1923; Norvell i Redhead 1994). Szczytowe komórki szybko kiełkują promieniście wytwarzając krótkie, rozgałęzione appressoria. Rozrastająca się grzybnia penetruje kutykulę, wnikając nawet do $14 \mu \mathrm{m}$ w głąb tkanki roślinnej (Peyronel 1923). Woda skraplająca się na powierzchni liści ułatwia kiełkowanie zarodników. Ważnym mechanizmem rozprzestrzeniania zarodników konidialnych jest również ich przenoszenie na butach czy też elementach maszyn (Hildebrand i Renderos 2007). Wynikiem nawiązania kontaktu pasożytniczego patogena $\mathrm{z}$ rośliną są objawy choroby na liściach w postaci koncentrycznych plam. W środkowej ich części przez kilka miesięcy można znaleźć konidia (Redhead i Perrin 1972a; Norvell i Redhead 1994). Z czasem powstaje grzybnia oplatająca nerwy główne liści, a następnie ich sklerotyzacja, zamieranie liści i defoliacja pędów (Norvell i Redhead 1994).

Grzyb zimuje na opadłych, porażonych liściach w postaci sklerocjów, z których rozwijają się apotecja. Znajdujące się w nich zarodniki workowe dokonują infekcji pierwotnych w nowym sezonie wegetacyjnym (Redhead 1974). Następnie na powstałych plamach dochodzi do wytworzenia staurokonidiów, które odpowiadają za rozprzestrzenianie $V$. heterodoxa na sąsiednie liście i rośliny (Redhead i Perrin 1972a; Norvell i Redhead 1994).

Chcąc zidentyfikować interakcje między grzybem a roślinami żywicielskimi na poziomie molekularnym, można zastosować analogię do innych przedstawicieli tej rodziny. Niektórzy właśnie na tej podstawie sugerują, że grzyb może posiadać geny odpowiedzialne za produkcję specyficznych enzymów odpowiedzialnych za rozkład kutykuli czy toksyn, które są w stanie wyłączyć lub unieszkodliwić reakcje obronne gospodarza (Vogelgsang i Shamoun 2004).

\section{V. heterodoxa jako bioherbicyd V. heterodoxa as a bioherbicide}

Biologiczna metoda zwalczania chwastów stanowi innowacyjne wykorzystanie działalności mikroorganiz- mów naturalnie występujących w środowisku. Jednym $\mathrm{z}$ takich gatunków jest $V$. heterodoxa, naturalnie występujący na Gaultheria shallon (Vogelgsang i Shamoun 2002, 2004; Magnussen i wsp. 2004; Wilkin i wsp. 2005; Zhao i Shamoun 2006). W przeszłości roślina ta stanowiła źródło energii dla ptaków i ssaków. Była także elementem tradycji rodowitych plemion zamieszkujących tereny dzisiejszej prowincji British Columbia w Kanadzie, a także była szeroko wykorzystywana w aranżacjach wnętrz (Norvell i Redhead 1994). Obecnie G. shallon stanowi bardzo poważny problem w lasach iglastych, gdyż utrudnia kiełkowanie nasion i zagłusza wzrost siewek. $Z$ tego względu stała się „chwastem”, którego eliminowanie jest już koniecznością. Mechaniczne usuwanie G. shallon jest bardzo trudne, ponieważ roślina wytwarza silnie rozbudowany system korzeniowy, a jej pędy szybko się ukorzeniają. Natomiast chemiczne herbicydy są mało skuteczne, gdyż gruba warstwa pokrywająca liście utrudnia translokację substancji czynnej do wnętrza tkanek. Szansą na ograniczenie jej występowania wydają się bioherbicydy zawierające mikroorganizmy (Vogelgsang i Shamoun 2002; Magnussen i wsp. 2004). Vogelgsang i Shamoun (2004) uzyskali szczep PFC $3027 \mathrm{~V}$. heterodoxa, który został zgłoszony do urzędu patentowego i jest wykorzystywany jako składnik preparatów biologicznych stosowanych przeciwko G. shallon. Ewentualne użycie tego grzyba jako składnika bioherbicydu w Polsce może spowodować duże zmiany w jego populacji.

\section{Ochrona przed $V$. heterodoxa Protection against $V$. heterodoxa}

W USA do ochrony przed $V$. heterodoxa zaleca się głównie zabiegi agrotechniczne, m.in. ograniczenie przemieszczania się ludzi i maszyn po terenie plantacji w czasie zwilżenia roślin, co zapobiega rozprzestrzenieniu grzyba przez zarodniki konidialne przenoszone na obuwiu i ubraniu. Po zauważeniu ognisk choroby zaleca się bezwzględnie usuwać i palić porażone rośliny. W Kanadzie natomiast do ochrony krzewów borówki niskiej przed $V$. heterodoxa zarejestrowano środek Pristine WG (boskalid + piraklostrobina). Zastosowanie środków chemicznych zawierających ww. substancje czynne może okazać się skuteczne również w Polsce w ochronie borówki wysokiej przed tym patogenem. Zwłaszcza, że preparat Signum 33WG posiadający w swym składzie te substancje jest już zarejestrowany do ochrony borówki przeciwko szarej pleśni.

\section{Wnioski / Conclusions}

1. Plamistość liści borówki wysokiej jest stosunkowo nową chorobą opisaną na roślinach tego gatunku w Polsce.

2. Rośliny należące do rodziny Ericaceae, w tym także borówka wysoka są szczególnie podatne na porażenie przez $V$. heterodoxa. Zakładanie plantacji towarowych na obrzeżach lasów, w których często rosną zakażone przez tego patogena rośliny borówki czarnej może zwiększać ryzyko wystąpienia plamistości liści na borówce wysokiej. 
3. Brak jest skutecznych metod zwalczania patogena, przestrzenianiu się grzyba. a zabiegi agrotechniczne zapobiegają jedynie roz-

\section{Literatura / References}

Aamlid D. 2000. Infections of Valdensinia heterodoxa and Pucciniastrum vaccinii on bilberry (Vaccinium myrtillus). Forest Pathology 30 (3): 135-139.

Allescher A. 1897. Diagnosen eineger neuer, meist im Jahre 1896 gesammelter Arten bayerischen Plize nebst Bemerkungen uber einige kristische Arten. Berichte der Bayerischen Botanischen Gesellschaft 5: 13-25.

Annis S., Yarborough D. 2009. Disease Valdensinia Leaf spot Disease [online]. The University of Mine-Cooperative Extension: Maine Wild Blueberries. http://umaine.edu/blueberries/factsheets/disease/valdensinia-leaf-spot-disease. [Accessed: 24.03.2014].

Bavendamm W. 1944. Valdensia heterodoxa, ein neuer Buchenschädling. Forstwissenschaftliches Centralblatt 66 (1): 54-60.

Dzięcioł R., Mirzwa-Mróz E., Zielińska E., Wińska-Krysiak M., Wakuliński W. 2014. Valdensinia heterodoxa Peyronel as a new pathogen of blueberry in Poland [online]. Plant Disease 98, p. 688. http://dx.doi.org/10.1094/PDIS-06-13-0644-PDN [Accessed: 24.10.2014].

Farr D.F., Rossman A.Y. 2013. Fungal Databases, Systematic Mycology and Microbiology Laboratory, ARS, USDA [online]. Retrieved December 5, 2013. http://nt.ars-grin.gov/fungaldatabases [Accessed: 24.03.2014].

Gjaerum H.B. 1970. En merkelig sopp pa blabaer. [A curious fungus on Vaccinium myrtillus]. Blyttia 28: 159-163.

Hildebrand P.D., Renderos W.E. 2007. Valdensinia leaf spot (Valdensinia heterodoxa) of commercial lowbush blueberry in Atlantic Canada: an emerging new threat. Canadian Journal of Plant Pathology 29, p. 90.

Kirk P.M., Cannon P.F., Minter D.W., Stalpers J.A. 2008. Ainsworth and Bisby's Dictionary of the Fungi. Wyd. X. CABI Europe-UK, CAB International, Wallingford, $771 \mathrm{pp}$.

Kujala V. 1946. Stornformige Diasporen bei Saliastrum (Gloeosporium) myrtilli (Allesch.). Kujala 22: 137-141.

Magnussen S., Vogelgsang S.F., Shamoun S. 2004. Nonlinear mixed models for repeated data assessment of time and temperature effects on conidia production in the fungus Valdensinia heterodoxa. Biocontrol 49: 47-62.

Mel'nik V.A. 1981. Valdensia heterodoxa Peyronel, an unusual but very common Hyphomycetes [Fungi]. Novosti sistematiki nizshikh rastenii - Akademiia nauk SSSR, Botanicheskii institut 18: 96-99.

Mułenko W., Woodward S. 1996. Plant parasitic hyphomycetes new to Britain. Mycologist 10: 69-72.

Mułenko W., Majewski T., Ruszkiewicz-Michalska M. 2008. A preliminary checklist of micromycetes in Poland. p. 508. In: "Biodiversity of Poland 9" (Z. Mirek, ed.). W. Szafer Institute of Botany, Polish Academy of Sciences, Kraków, 752 pp.

Nekoduka S., Kanematsu S., Tanaka K., Harada Y., Sano T. 2012. Valdensinia leaf blight of blueberry caused by Valdensinia heterodoxa, a new fungal disease in Japan. Journal of General Plant Pathology 78 (3): 151-159.

Norvell L.L., Redhead S.A. 1994. Valdensinia heterodoxa (Sclerotiniaceae) in the United States. Canadian Journal of Forest Research 24: 1981-1983.

Parmelee J.A. 1988. Parasitic fungi of Newfoundland based on specimens from Gros Morne National Park. The Canada Field-Naturalist 102: 442-464.

Petrak F. 1962. Ergebnisse einer Revision der Grundtypen verschiedener Gattungen der Askomyzeten und Fungi Imperfecti. Sydowia 15: 185-193.

Peyronel B. 1923. Sopra un singolare parassita polifago: Valdensia heterodoxa $\mathrm{n}$. gen et n. sp. [On a singular polyphagous parasite: Valdensia heterodoxa n. gen. et n. sp.]. Stazione Sperimentale di Agrumicoltura Italiane 56: 521-538.

Peyronel B. 1953. La forma ascofora di Valdensia heterodoxa Peyronel, tipo di un nuovo genere di Sclerotiniacee: Valdensinia. Nuovo Giornale Botanico Italiane 59: 181-185.

Redhead S.A., Perrin P.W. 1972a. Asterobolus: a new parasitic hyphomycete with a novel dispersal mechanism. Canadian Journal of Botany 50: 409-412.

Redhead S.A., Perrin P.W. 1972b. Asterobolus: a synonym of Valdensia. Canadian Journal of Botany 50: 2083-2084

Redhead S.A. 1974. Epistolae mycologicae IV. Valdensinia heterodoxa Peyr. (Sclerotiniaceae). Syesis 7: 235-238.

Redhead S.A. 1979. Mycological observations: 1, on Cristulariella; 2, on Valdensinia; 3, on Neolecta. Mycologia 71: 1248-1253.

Siemaszko W. 1929. Phytopathologische Beobachtungen in Polen. Centralblatt für Bakteriologie, Parasitenkunde und Infektionskrankheiten 78: 113-116.

Siemaszko W. 1933. Quelques observations sur les maladies des plantem en Polone. Revue de Pathologie Végétale et d'Entomologie Agricole 20: 139-148.

Siemaszko W. 1934. Zagadnienia zasięgów geograficznych chorób roślin uprawnych. Rocznik Nauk Ogrodniczych 1: $163-170$.

Treigienè A. 1998. Valdensia heterodoxa Peyr. in Lithuania. Botanica Lithuanica 4 (1): 99-102.

Vogelgsang S., Shamoun S.F. 2002. Growth, sporulation, and conidia discharge of Valdensinia heterodoxa, a foliar pathogen of salal, as influenced by temperature and photoperiod in vitro. Mycological Research 106: 480-490.

Vogelgsang S., Shamoun S.F. 2004. Evaluation of an inoculum production and delivery technique for Valdensinia heterodoxa, a potential biological control agent for salal. Biocontrol Science and Technology 14: 747-756.

Wilkin J.E. 2004. Genetic diversity and population structure of the potential biocontrol agent, Valdensinia heterodoxa, and its host Gaultheria shallon (salal). M.Sc. Thesis, Department of Forest Sciences, The University of British Columbia, Vancouver, B.C., Canada: 6-7.

Wilkin J.E., Shamoun S.F., Ritland C., Ritland K., El-Kassaby Y.A. 2005. Population genetics of Gaultheria shallon In British Columbia and the implications for management using biocontrol. Canadian Journal of Botany 83: 501-509.

Zhao S., Shamoun S.F. 2006. The effects of culture media, solid substrates, and relative humidity on growth, sporulation and conidial discharge of Valdensinia heterodoxa. Mycological Research 110: 1340-1346.

Zhao S., Shamoun S.F. 2010. Conidial morphology, structure and development in Valdensinia heterodoxa. Mycology 1: 113-120. 